\title{
Seasonal Variations in the Uptake and Status of the Secondary Nutrients in Leaf Terminals in Cashew in Coastal Districts of Andhra Pradesh, India
}

\author{
N. Sathi Babu ${ }^{1 *}$, V. Chandra Sekhar ${ }^{2}$ and K. Dhanasree ${ }^{3}$ \\ ${ }^{1}$ Department of Horticulture, Agricultural College, Bapatla, Andhra Pradesh-522101, India \\ ${ }^{2}$ Department of Plant pathology, Agricultural College, Naira, Srikakulam, \\ Andhra Pradesh, India \\ ${ }^{3}$ Department of Agricultural Extension, Agricultural College, Rajendranagar, \\ Andhra Pradesh, India \\ *Corresponding author
}

\begin{abstract}
A B S T R A C T
Investigations on the seasonal fluctuations in the uptake and status of the secondary nutrients $(\mathrm{Ca}, \mathrm{Mg}$ and $\mathrm{S})$ in both fruiting and non-fruiting terminals in cashew carried out

\section{Keywords}

Cashew (Anacardium occidentale L.),

Secondary nutrients, Leaf Terminals

\section{Article Info}

Accepted:

26 August 2018

Available Online:

10 September 2018 during 2006 and 2007 in twelve plantations spread over the cashew growing districts of north coastal Andhra Pradesh revealed that the nutrient contents ranged from 0.216 to $1.532 \%$ (low to high), 0.132 to $0.226 \%$ (low to adequate) and 0.087 to $0.174 \%$ (low to high) with respect to $\mathrm{Ca}, \mathrm{Mg}$, and $\mathrm{S}$, respectively. In both cases, the peak was observed during September to November, indicating depletion of the nutrients due to mobility to the developing fruits. Thereafter, there was a decline in leaf $\mathrm{Ca}$ content, possibly due to utilization by sinks of initiation and differentiation of flower buds. As regards $\mathrm{Mg}$, the non-fruiting terminals in general recorded higher uptake during the same period and a declining trend was observed from May to July. There was increase in leaf S from July to January followed by a decline thereafter till March. Presumably, the greater nutrient concentration in both fruiting and non-fruiting terminals during the period of November to January coincided with the flower bud initiation and formative stage of the plant. Nonfruiting terminals showed higher nutrient contents in comparison to the fruiting terminals during all the months under study.
\end{abstract}

\section{Introduction}

Cashew (Anacardium occidentale L.) is an important revenue generating crop in north coastal Andhra Pradesh. However, there is much scope to increase its yield through nutrient management. Reports on nutrient uptake and management in cashew grown in the area is very meager, more so with respect to the secondary nutrients $(\mathrm{Ca}, \mathrm{Mg}$, and $\mathrm{S})$.
Plant Tissue analysis is an established effective tool for plant diagnosis, while leaf, a major metabolic centre, is an ideal choice for carrying out such plant tissue analysis studies for the uptake and requirement of nutrients, and work out a fertilizer schedule based on the results of such studies. The mineral composition of leaves varies due to several factors (Kumar et al., 1985). An investigation was accordingly undertaken to study the 
seasonal fluctuations in the uptake and status of the secondary nutrients during the growth phases in both fruiting terminals and nonfruiting terminals with the principal objective of designing an effective fertilizer programme for the plant cultivated in north coastal Andhra Pradesh.

\section{Materials and Methods}

Plantations located within twelve mandals (Tekkali, S. Bommalli, R. B. Puram, Rolugunta, Salur, Narsipatnam, Nidadavol, J. R.Gudem, Vetapalem, Chinnaganjam, Bapatla and Karlapalem) were selected. Five uniform 'look like' trees from around ten years old plantation from each mandal were selected at random, and leaf samples from fruiting and non-fruiting terminals of the selected trees were collected at bimonthly intervals from July 2006 to May 2007. The fifth leaf from the terminal bud was chosen and such leaves from all four sides of the trees were collected from fruiting and non-fruiting terminals as followed by Chapman (1964). Standard methods were followed for the determination of $\mathrm{Ca}, \mathrm{Mg}$ (Jackson, 1973), and S (Cottenie et al., 1979). The observations recorded in field and laboratory from different treatments were subjected to statistical analysis by adopting randomized block design as described by Panse and Sukhatme (1967).

\section{Results and Discussion}

The results on periodical analysis for (Table 1) revealed that the leaf $\mathrm{Ca}$ content ranged from $0.216 \%$ in fruiting terminal during May in plantations of Chinnaganjam mandal, Prakasam district to $1.532 \%$ in non- fruiting terminals during November in plantations of Rolugunta mandal, Visakhapatnam district. Ca content ranged from low to high in accordance to the leaf analysis standards followed by Robinson et al., (1997) for diagnosing nutrient status in cashew (Table 4). Plants in some of the plantations were low in leaf $\mathrm{Ca}$ during different months under study suggesting in undertaking further studies on the aspect. Sanyal and Mitra (1991) reported that Ca content ranged from 0.38 to $0.48 \%$ in cashew grown in different areas of West Bengal. Likewise, Richards (1993) reported that Ca content ranged from 0.10 to $0.54 \%$, while Jagadeshkumar (2005) reported 0.09 to $0.16 \%$ in different varieties in Kerala. Further, much difference with regard to leaf $\mathrm{Ca}$ content in fruiting and non-fruiting terminals was observed during all the months of study; also, there were appreciable differences among the mandals with regard to the leaf nutrient (Fig. 1). $\mathrm{Ca}$ is practically immobile and therefore, its supply at a time when required for metabolic activity and normal growth is a must, failing which various physiological disorders like reduction in growth and root system, deformed multiple buds etc. are observed; the disorders as stated eventually result in reduced yield in terms of both quantity and quality.

As regards the mean leaf $\mathrm{Ca}$ content in fruiting and non- fruiting terminals, the peak was observed during the months of September and November, indicating depletion of nutrients due to consequent mobility of $\mathrm{Ca}$ to developing fruits (Fig. 2). It could be due to $\mathrm{CaCO}_{3}$ present in the soils in high amounts and due to relatively immobile nature of $\mathrm{Ca}$ in plants resulting in accumulation in leaves. The results of this study are in conformity with those of Thakur et al., (1981), and Bopaiah et al., (1989). There was a decline in leaf Ca content after November, possibly because of leaf $\mathrm{Ca}$ having been utilized by sinks of flower bud initiation and differentiation.

Leaf $\mathrm{Mg}$ content ranged from $0.141 \%$ in fruiting terminals in plantations of Vetapalm mandal of Prakasam district during May to $0.234 \%$ in non-fruiting terminals in plantations of Rolugunta mandals of 
Visakhapatnam district during November (Table 2). Sanyal and Mitra (1991) reported that $\mathrm{Mg}$ content ranged from 0.15 to $0.22 \%$ in cashew grown in different parts of West Bengal, while Richards (1993) reported the same to range from 0.16 to $0.34 \%$. Jagadeshkumar (2005) reported that leaf $\mathrm{Mg}$ content in different varieties of cashew grown in plantations of Kasargod area in Kerala ranged from $81.3 \mathrm{ppm}(\mathrm{Cv} . \mathrm{H}-2 / 16)$ to 172.2 ppm (Cv.VTL-53/2). Further, in the plantations in almost all the mandals, the mean leaf $\mathrm{Mg}$ content was found to be in 'low' category in accordance to the leaf nutrient guide of Robinson et al., (1997). The nutrient guide as stated is presented in Table 4. Also, the leaf $\mathrm{Mg}$ content was found to decline from July to May in both fruiting and non-fruiting terminals, indicating that there is a need to provide $\mathrm{Mg}$, since the nutrient is more critically involved in plant metabolic process during that period. The results further revealed that the leaf $\mathrm{Mg}$ in cashew grown in all the plantations were in 'low' category. Comparatively higher values were observed during September and November in both fruiting and non-fruiting terminals (Fig. 3). Similar results were also reported by Chadha et al., (1984) who stated that the drain of nutrients might be due to its translocation to the developing fruits. Beena Bhaskar (1992) reported that the concentrations of $\mathrm{Mg}$ were higher during post-harvest phase than in the fruiting phase of the plant. Koo and Young (1977), Bopaiah and Srivastava (1984) Bopaiah et al., (1989), and Kotur and Singh (1993) reported similar results in the case of the primary and secondary nutrients viz. $\mathrm{N}$, $\mathrm{P}, \mathrm{K}, \mathrm{Ca}$ and $\mathrm{Mg}$ in other fruit trees, and proposed similar reasoning too.

The mean leaf Mg content declined from July to May (Fig. 4) in different mandals. However, during the same period, $\mathrm{K}$ content increased unlike the case with $\mathrm{Mg}$, confirming that $\mathrm{K}$ and $\mathrm{Mg}$ are antagonistic to each other.
These results also suggest that while applying potassic fertilizers, necessary steps are to be adopted in such manner that the increased supply of $\mathrm{K}$ in no way proves detrimental to the supply of $\mathrm{Mg}$ to the plants. Srivastava and Singh (2003) also reported similar antagonistic relationship between $\mathrm{K}$ and $\mathrm{Mg}$ in sweet orange.

The monthly mean leaf $\mathrm{S}$ content in fruiting and non-fruiting terminals in cashew plantations in all the mandals showed significant differences and ranged from $0.087 \%$ in fruiting terminals during May in Bapatla mandal of Guntur district to $0.174 \%$ in non-fruiting terminals during January in Jagareddygudeum mandal of West Godavari district (Table 3). Sanyal and Mitra (1991) reported that leaf $S$ content ranged from 0.125 to $0.141 \%$ in cashew grown in West Bengal. $\mathrm{S}$ is a constituent of $\mathrm{S}$ containing amino acids, and is thus involved in the synthesis of proteins and enzymes; $S$ is also involved in nitrogen metabolism and its disulphide linkage is intimately associated with the structure of protoplasm; the function of $\mathrm{S}$ is thus of great metabolic significance.

In accordance to the leaf nutrient guide of Robinson et al., (1997) (Table 4), the leaf S content in cashew was 'low' in plantations of all the mandals of all the districts. The deficiency of $S$ may result in biochemical disorders resulting in reduction in plant growth with typical chlorotic symptoms. Under such circumstances, it is necessary to ensure immediate supply of $\mathrm{S}$ through either inorganic or organic sources.

The non-fruiting terminals contained more leaf $S$ than the fruiting terminals (Fig. 5). The mean leaf $S$ content was found to be increasing from July to January and thereafter, it decreased till March (Fig. 6). The decline as stated might be due to utilization of the nutrient for fruit development. 
Table.1 Month wise mean leaf $\mathrm{Ca}$ content (\%) of fruiting and non-fruiting terminals (FT and NFT) in cashew

\begin{tabular}{|c|c|c|c|c|c|c|c|c|c|c|c|c|c|c|}
\hline \multirow[t]{2}{*}{ Plantations } & \multicolumn{2}{|c|}{ Jul-06 } & \multicolumn{2}{|c|}{ Sep-06 } & \multicolumn{2}{|c|}{ Nov-06 } & \multicolumn{2}{|c|}{ Jan-07 } & \multicolumn{2}{|c|}{ Mar-07 } & \multicolumn{2}{|c|}{ Мay-07 } & \multicolumn{2}{|c|}{ Mean } \\
\hline & FT & NFT & FT & NFT & FT & NFT & FT & NFT & FT & NFT & FT & NFT & FT & NFT \\
\hline Tekkali & 0.512 & 0.584 & 1.194 & 1.374 & 1.285 & 1.395 & 0.377 & 0.391 & 0.356 & 0.365 & 0.235 & 0.367 & 0.660 & 0.746 \\
\hline S. Bommalli & 0.542 & 0.598 & 1.224 & 1.405 & 1.352 & 1.425 & 0.409 & 0.423 & 0.383 & 0.394 & 0.266 & 0.393 & 0.696 & 0.773 \\
\hline Salur & 0.476 & 0.508 & 1.192 & 1.384 & 1.408 & 1.431 & 0.418 & 0.443 & 0.353 & 0.365 & 0.247 & 0.371 & 0.682 & 0.750 \\
\hline R. B. Puram & 0.478 & 0.537 & 1.223 & 1.402 & 1.438 & 1.423 & 0.412 & 0.431 & 0.387 & 0.398 & 0.279 & 0.402 & 0.703 & 0.766 \\
\hline Rolugunta & 0.538 & 0.547 & 1.195 & 1.375 & 1.516 & 1.532 & 0.408 & 0.452 & 0.341 & 0.356 & 0.234 & 0.366 & 0.705 & 0.771 \\
\hline Narsipatnam & 0.508 & 0.526 & 1.214 & 1.359 & 1.395 & 1.415 & 0.402 & 0.416 & 0.410 & 0.384 & 0.256 & 0.382 & 0.698 & 0.747 \\
\hline Nidadavol & 0.475 & 0.505 & 1.215 & 1.385 & 1.372 & 1.394 & 0.416 & 0.428 & 0.393 & 0.406 & 0.267 & 0.394 & 0.690 & 0.752 \\
\hline J.R. Gudem & 0.532 & 0.521 & 1.238 & 1.453 & 1.428 & 1.458 & 0.412 & 0.424 & 0.378 & 0.387 & 0.255 & 0.384 & 0.707 & 0.771 \\
\hline Vetapalem & 0.511 & 0.517 & 1.156 & 1.345 & 1.350 & 1.403 & 0.331 & 0.345 & 0.365 & 0.375 & 0.246 & 0.378 & 0.660 & 0.727 \\
\hline Chinnaganjam & 0.476 & 0.486 & 1.214 & 1.388 & 1.298 & 1.394 & 0.388 & 0.402 & 0.308 & 0.314 & 0.216 & 0.345 & 0.650 & 0.722 \\
\hline Bapatla & 0.429 & 0.465 & 1.178 & 1.352 & 1.323 & 1.372 & 0.359 & 0.373 & 0.332 & 0.345 & 0.186 & 0.309 & 0.635 & 0.703 \\
\hline Karlapalem & 0.426 & 0.443 & 1.194 & 1.374 & 1.321 & 1.367 & 0.377 & 0.391 & 0.354 & 0.364 & 0.218 & 0.354 & 0.648 & 0.716 \\
\hline Range & $\begin{array}{l}0.426 \\
0.542\end{array}$ & $\begin{array}{l}0.443 \\
0.598\end{array}$ & $\begin{array}{l}1.156 \\
1.238\end{array}$ & $\begin{array}{l}1.345 \\
1.453\end{array}$ & $\begin{array}{l}1.298 \\
1.516\end{array}$ & $\begin{array}{l}1.367 \\
1.532\end{array}$ & $\begin{array}{l}0.331 \\
0.418\end{array}$ & $\begin{array}{l}0.345 \\
0.452\end{array}$ & $\begin{array}{l}0.308 \\
0.393\end{array}$ & $\begin{array}{l}0.314 \\
0.406\end{array}$ & $\begin{array}{l}0.216 \\
0.279\end{array}$ & $\begin{array}{l}0.309 \\
0.402\end{array}$ & & \\
\hline Mean & 0.492 & 0.520 & 1.203 & 1.383 & 1.374 & 1.417 & 0.392 & 0.410 & 0.363 & 0.371 & 0.242 & 0.370 & & \\
\hline SEm+ & 0.08 & 0.08 & 0.07 & 0.07 & 0.04 & 0.04 & 0.01 & 0.01 & 0.02 & 0.01 & 0.01 & 0.01 & & \\
\hline $\mathrm{CD}(0.05)$ & 0.21 & 0.21 & 0.19 & 0.19 & 0.14 & 0.12 & 0.04 & 0.04 & 0.03 & 0.03 & 0.02 & 0.03 & & \\
\hline $\mathrm{CV}(\%)$ & 8.81 & 8.46 & 12.72 & 11.24 & 7.99 & 7.07 & 8.28 & 7.23 & 7.86 & 6.98 & 7.47 & 7.20 & & \\
\hline
\end{tabular}

Table.2 Month wise mean leaf Mg content (\%) of fruiting and non-fruiting terminals (FT and NFT) in cashew

\begin{tabular}{|c|c|c|c|c|c|c|c|c|c|c|c|c|c|c|}
\hline \multirow[t]{2}{*}{ Plantations } & \multicolumn{2}{|c|}{ Jul-06 } & \multicolumn{2}{|c|}{ Sep-06 } & \multicolumn{2}{|c|}{ Nov-06 } & \multicolumn{2}{|c|}{ Jan-07 } & \multicolumn{2}{|c|}{ Mar-07 } & \multicolumn{2}{|c|}{ Маy-07 } & \multicolumn{2}{|c|}{ Mean } \\
\hline & FT & NFT & FT & NFT & FT & NFT & FT & NFT & FT & NFT & FT & NFT & FT & NFT \\
\hline Tekkali & 0.181 & 0.192 & 0.187 & 0.218 & 0.197 & 0.218 & 0.185 & 0.215 & 0.182 & 0.186 & 0.181 & 0.193 & 0.186 & 0.204 \\
\hline S. Bommalli & 0.184 & 0.195 & 0.158 & 0.189 & 0.186 & 0.207 & 0.153 & 0.187 & 0.178 & 0.190 & 0.152 & 0.164 & 0.169 & 0.189 \\
\hline Salur & 0.209 & 0.211 & 0.179 & 0.210 & 0.206 & 0.227 & 0.177 & 0.218 & 0.181 & 0.187 & 0.175 & 0.187 & 0.188 & 0.207 \\
\hline R. B. Puram & 0.204 & 0.215 & 0.181 & 0.212 & 0.204 & 0.226 & 0.180 & 0.210 & 0.184 & 0.192 & 0.173 & 0.184 & 0.189 & 0.208 \\
\hline Rolugunta & 0.206 & 0.217 & 0.182 & 0.213 & 0.213 & 0.224 & 0.185 & 0.211 & 0.181 & 0.190 & 0.179 & 0.191 & 0.190 & 0.209 \\
\hline Narsipatnam & 0.208 & 0.219 & 0.179 & 0.211 & 0.194 & 0.211 & 0.174 & 0.185 & 0.177 & 0.187 & 0.152 & 0.164 & 0.181 & 0.197 \\
\hline Nidadavol & 0.215 & 0.226 & 0.189 & 0.220 & 0.198 & 0.209 & 0.182 & 0.200 & 0.172 & 0.180 & 0.161 & 0.173 & 0.186 & 0.201 \\
\hline J.R. Gudem & 0.211 & 0.222 & 0.192 & 0.223 & 0.208 & 0.229 & 0.187 & 0.210 & 0.179 & 0.191 & 0.178 & 0.190 & 0.193 & 0.211 \\
\hline Vetapalem & 0.175 & 0.186 & 0.152 & 0.183 & 0.196 & 0.217 & 0.150 & 0.181 & 0.181 & 0.185 & 0.141 & 0.152 & 0.166 & 0.184 \\
\hline Chinnaganjam & 0.183 & 0.191 & 0.133 & 0.164 & 0.175 & 0.195 & 0.153 & 0.183 & 0.180 & 0.183 & 0.156 & 0.168 & 0.163 & 0.181 \\
\hline Bapatla & 0.158 & 0.169 & 0.155 & 0.186 & 0.177 & 0.198 & 0.132 & 0.161 & 0.176 & 0.184 & 0.163 & 0.172 & 0.160 & 0.178 \\
\hline Karlapalem & 0.162 & 0.173 & 0.137 & 0.168 & 0.173 & 0.194 & 0.135 & 0.165 & 0.175 & 0.179 & 0.151 & 0.163 & 0.156 & 0.174 \\
\hline Range & 0.158 & 0.169 & 0.133 & 0.164 & 0.179 & 0.194 & 0.132 & 0.161 & 0.175 & 0.179 & 0.141 & 0.152 & & \\
\hline & 0.215 & 0.226 & 0.192 & 0.223 & 0.213 & 0.234 & 0.187 & 0.218 & 0.184 & 0.192 & 0.181 & 0.193 & & \\
\hline Mean & 0.191 & 0.201 & 0.169 & 0.200 & 0.194 & 0.214 & 0.166 & 0.194 & 0.179 & 0.186 & 0.164 & 0.175 & & \\
\hline SEm+ & 0.05 & 0.02 & 0.02 & 0.01 & 0.01 & 0.01 & 0.01 & 0.01 & 0.01 & 0.01 & 0.01 & 0.04 & & \\
\hline $\mathrm{CD}(0.05)$ & 0.01 & 0.01 & 0.01 & 0.02 & 0.01 & 0.02 & 0.01 & 0.02 & 0.03 & 0.02 & 0.01 & 00.1 & & \\
\hline CV (\%) & 6.05 & 5.98 & 6.08 & 5.97 & 6.03 & 6.02 & 6.07 & 6.07 & 7.95 & 6.08 & 5.78 & 5.84 & & \\
\hline
\end{tabular}


Table.3 Month wise mean leaf S content (\%) of fruiting and non-fruiting terminals (FT and NFT) in cashew

\begin{tabular}{|c|c|c|c|c|c|c|c|c|c|c|c|c|c|c|}
\hline \multirow[t]{2}{*}{ Plantations } & \multicolumn{2}{|c|}{ Jul-06 } & \multicolumn{2}{|c|}{ Sep-06 } & \multicolumn{2}{|c|}{ Nov-06 } & \multicolumn{2}{|c|}{ Jan-07 } & \multicolumn{2}{|c|}{ Mar-07 } & \multicolumn{2}{|c|}{ Мay-07 } & \multicolumn{2}{|c|}{ Mean } \\
\hline & FT & NFT & FT & NFT & FT & NFT & FT & NFT & FT & NFT & FT & NFT & FT & NFT \\
\hline ekkali & 0.139 & 0.151 & 0.123 & 0.140 & 0.121 & 0.126 & 0.142 & 0.170 & 0.092 & 0.110 & 0.111 & 0.121 & 0.121 & 0.138 \\
\hline Bon & 126 & 0.145 & 124 & 0.142 & 0.123 & 0.129 & 0.144 & 0.172 & 0.095 & 0.112 & 0.110 & 0.130 & 0.120 & 0.139 \\
\hline alur & 124 & .143 & 120 & 0.138 & 0.112 & 0.122 & 0.130 & 0.150 & 0.094 & 0.098 & 0.106 & 0.112 & 0.114 & 0.127 \\
\hline B. Puram & 122 & 0.124 & 0.094 & 0.108 & 0.104 & 0.100 & 0.132 & 0.138 & 0.095 & 0.094 & 0.098 & 0.105 & 0.108 & 0.112 \\
\hline olugunta & 126 & 0.145 & 0.121 & 0.140 & 0.114 & 0.124 & 0.131 & 0.141 & 0.094 & 0.098 & 0.108 & 0.114 & 0.116 & 0.127 \\
\hline arsipatnam & 120 & 0.140 & 119 & 0.138 & 0.112 & 0.121 & 0.129 & 0.148 & 0.091 & 0.090 & 0.106 & 0.120 & 0.113 & 0.126 \\
\hline . & 132 & 0.154 & 113 & 0.143 & 0.126 & 0.132 & 0.136 & 0.171 & 0.110 & 0.111 & 0.102 & 0.124 & 0.120 & 0.139 \\
\hline & & & & & & & & & & & & & & \\
\hline Vetapalem & 120 & 0.122 & 0.092 & 0.106 & 0.102 & 0.098 & 0.128 & 0.132 & 0.094 & 0.089 & 0.094 & 0.106 & 0.105 & 0.109 \\
\hline Chinnaganjam & 0.113 & 0.115 & 0.088 & 0.103 & 0.100 & 0.094 & 0.123 & 0.120 & 0.091 & 0.095 & 0.090 & 0.104 & 0.101 & 0.105 \\
\hline Bapatla & 116 & 0.119 & 0.084 & 0.101 & 0.098 & 0.100 & 0.120 & 0.124 & 0.089 & 0.093 & 0.087 & 0.101 & 0.099 & 0.106 \\
\hline Karlapal & & 0.117 & 090 & 105 & 0.102 & .098 & 125 & 0.130 & 0.092 & 0.098 & 0.092 & 0.106 & 0.103 & 0.109 \\
\hline \multirow[t]{2}{*}{ Range } & 113 & 0.115 & 0.084 & 0.101 & 0.098 & 0.094 & 0.120 & 0.120 & 0.089 & 0.089 & 0.087 & 0.101 & & \\
\hline & 0.142 & 0.160 & 0.126 & 0.148 & 0.126 & 0.132 & 0.146 & 0.174 & 0.110 & 0.112 & 0.112 & 0.131 & & \\
\hline Mean & 0.125 & 0.136 & 0.108 & 0.126 & 0.111 & 0.115 & 0.132 & 0.148 & 0.094 & 0.100 & 0.101 & 0.115 & & \\
\hline SEm+ & 0.08 & 0.08 & 0.07 & 0.07 & 0.04 & 0.04 & 0.01 & 0.01 & 0.02 & 0.01 & 0.01 & 0.01 & & \\
\hline 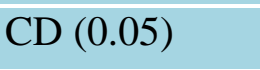 & 0.01 & 0.01 & 0.01 & 0.01 & 0.01 & 0.01 & 0.01 & 0.01 & 0.01 & 0.01 & 0.01 & 0.01 & & \\
\hline $\mathrm{CV}(\%)$ & 7.51 & 7.16 & 7.44 & 7.70 & 7.52 & 7.45 & 6.79 & 7.33 & 7.52 & 7.36 & 7.63 & 7.44 & & \\
\hline
\end{tabular}

Table.4 Leaf nutrient guide for cashew (Robinson et al., 1997)

\begin{tabular}{|c|c|c|c|c|}
\hline Nutrient & Deficient & Low & Adequate & High \\
\hline $\mathbf{N} \%$ & $<1.38$ & $1.39-2.39$ & $2.40-2.58$ & $>2.58$ \\
\hline $\mathrm{p} \%$ & $<0.14$ & $0.141-0.15$ & $0.16-0.20$ & $>\mathbf{0 . 2 0}$ \\
\hline $\mathrm{K} \%$ & $<0.26$ & $0.27-1.09$ & $1.10-1.20$ & $>1.20$ \\
\hline $\mathrm{S} \%$ & $<0.08$ & $0.09-0.10$ & $0.11-0.14$ & $>0.14$ \\
\hline $\mathrm{Ca} \%$ & $<0.11$ & $0.10-0.23$ & $0.24-0.75$ & $>\mathbf{0 . 7 5}$ \\
\hline $\mathrm{Mg} \%$ & $<0.11$ & $0.10-0.21$ & $0.22-0.31$ & $>\mathbf{0 . 3 1}$ \\
\hline $\mathrm{Cu}\left(\mathrm{mg} \mathrm{kg}^{-1}\right)$ & $<7$ & - & $>7$ & - \\
\hline $\mathrm{Zn}\left(\mathrm{mg} \mathrm{kg}^{-1}\right)$ & $<12$ & $13-20$ & $>20$ & - \\
\hline $\mathrm{Mn}\left(\mathrm{mg} \mathrm{kg}^{-1}\right)$ & $<26$ & $27-90$ & $91-204$ & $>204$ \\
\hline $\mathbf{F e}\left(\mathrm{mg} \mathrm{kg}^{-1}\right)$ & $<92$ & $95-147$ & $148-165$ & $>165$ \\
\hline $\mathbf{B}\left(\mathrm{mg} \mathrm{kg}^{-1}\right)$ & $<39$ & $40-55$ & $56-67$ & $>67$ \\
\hline
\end{tabular}


Fig.1 Mean leaf Ca content of cashew in different mandals

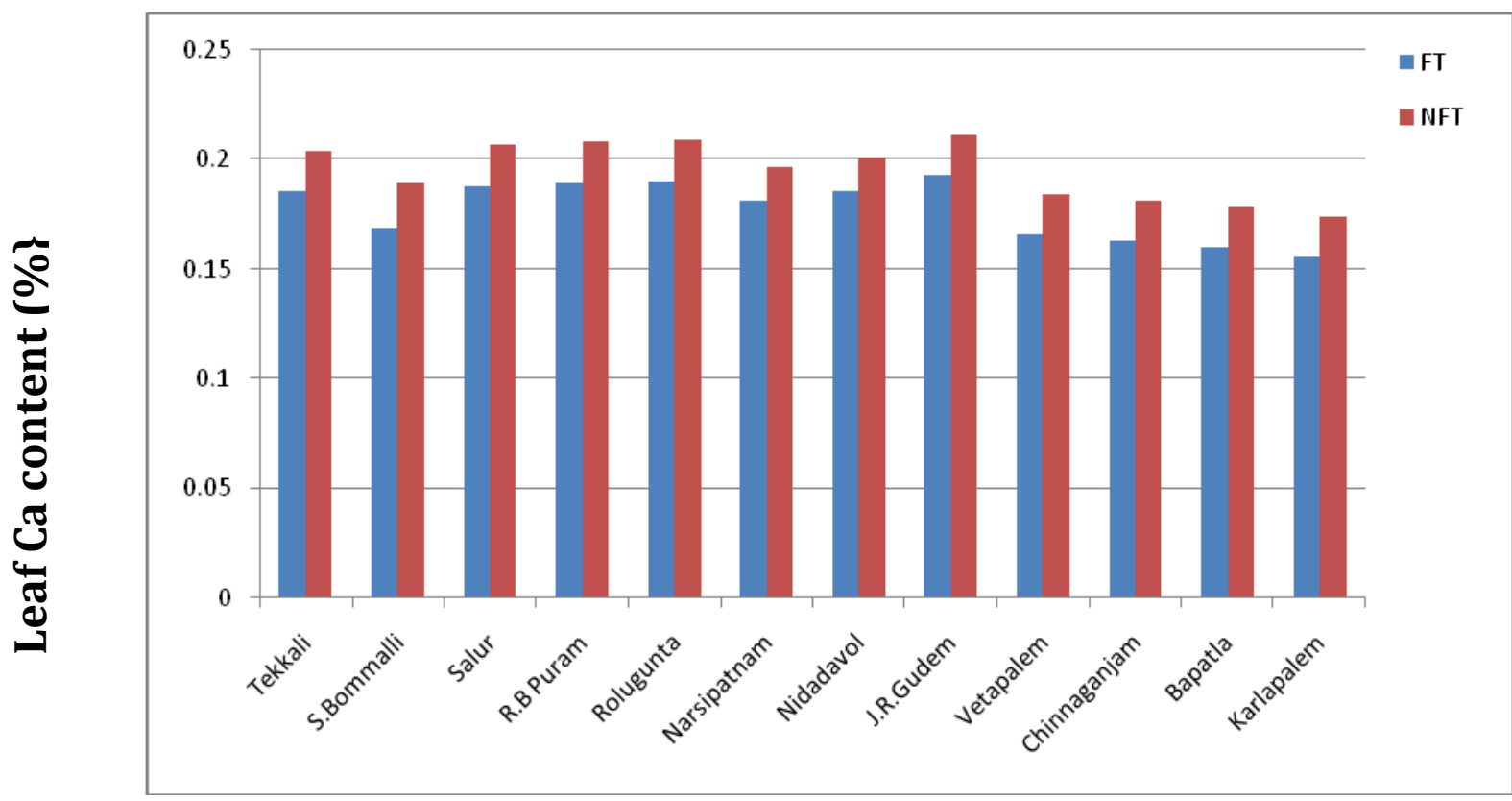

\section{Different Mandals}

Fig.2 Mean leaf Ca content of cashew during different months

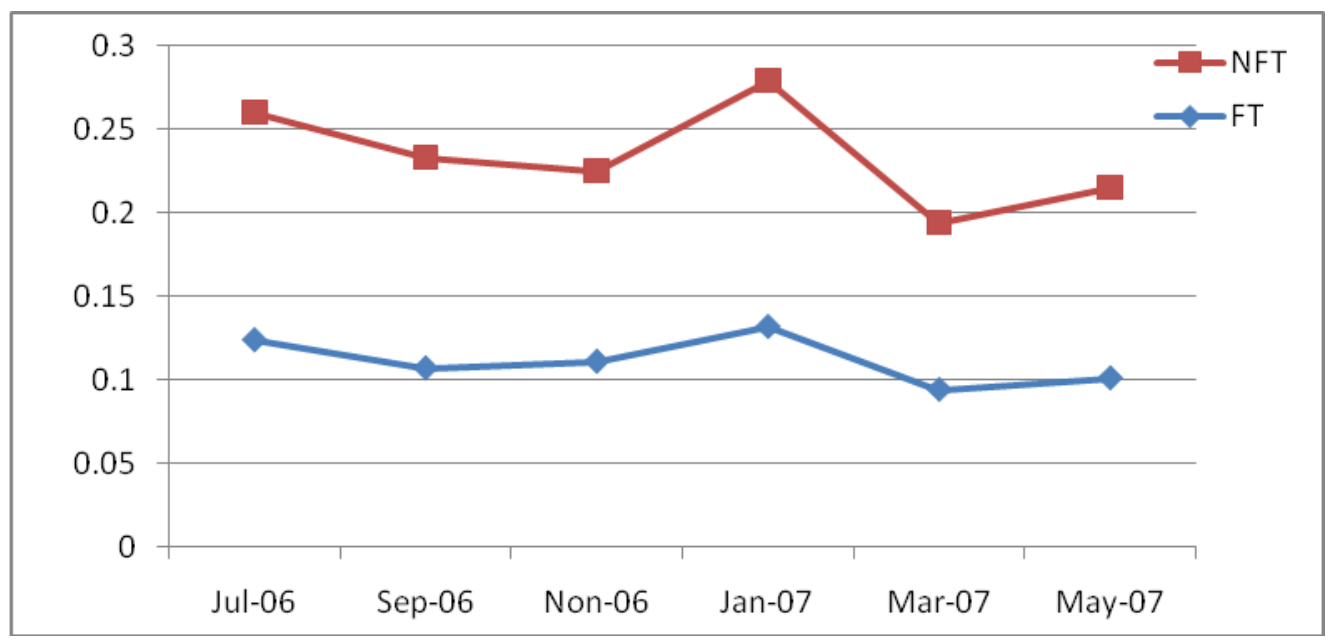

Months 
Fig.3 Mean leaf $\mathrm{Mg}$ content of cashew in different mandals

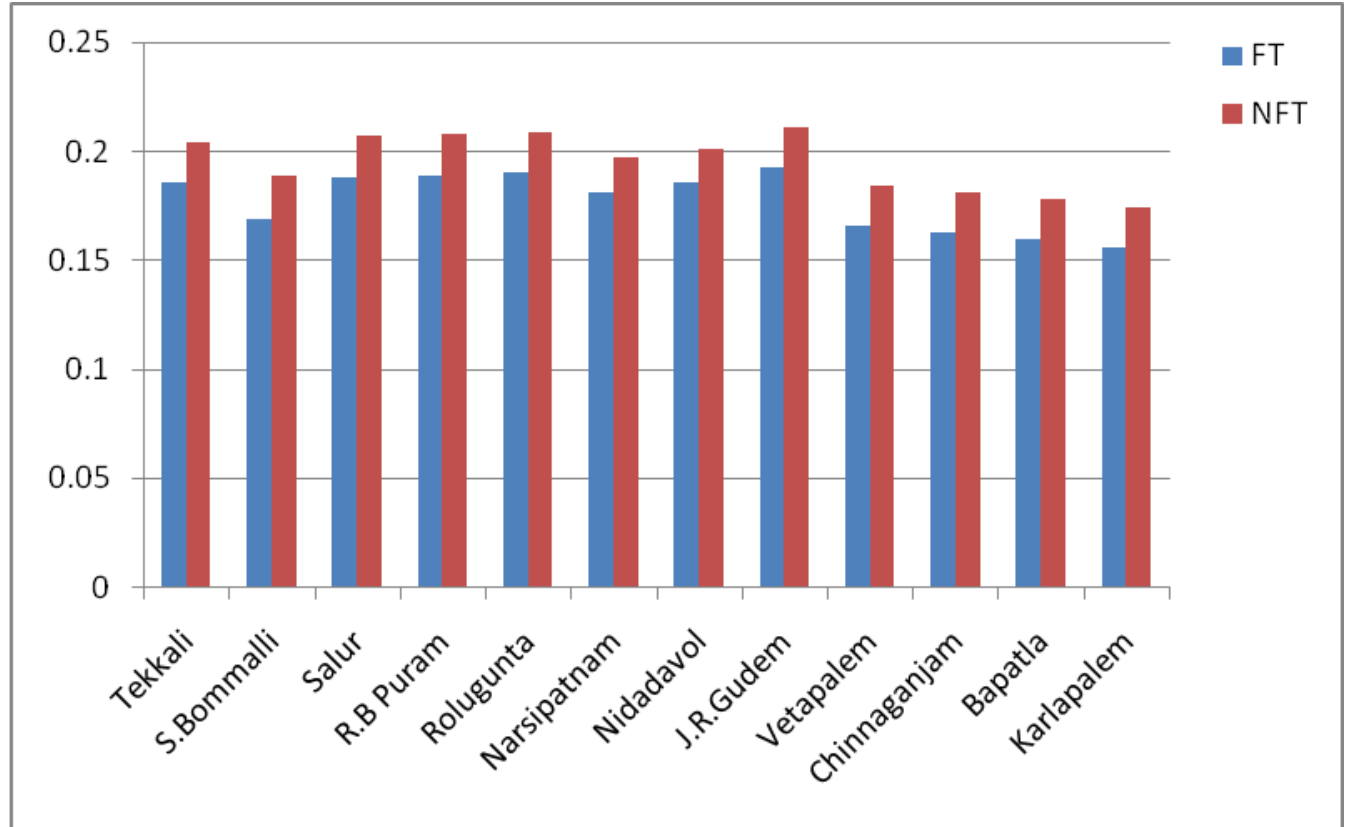

\section{Different mandals}

Fig.4 Mean leaf Mg content of cashew in different months

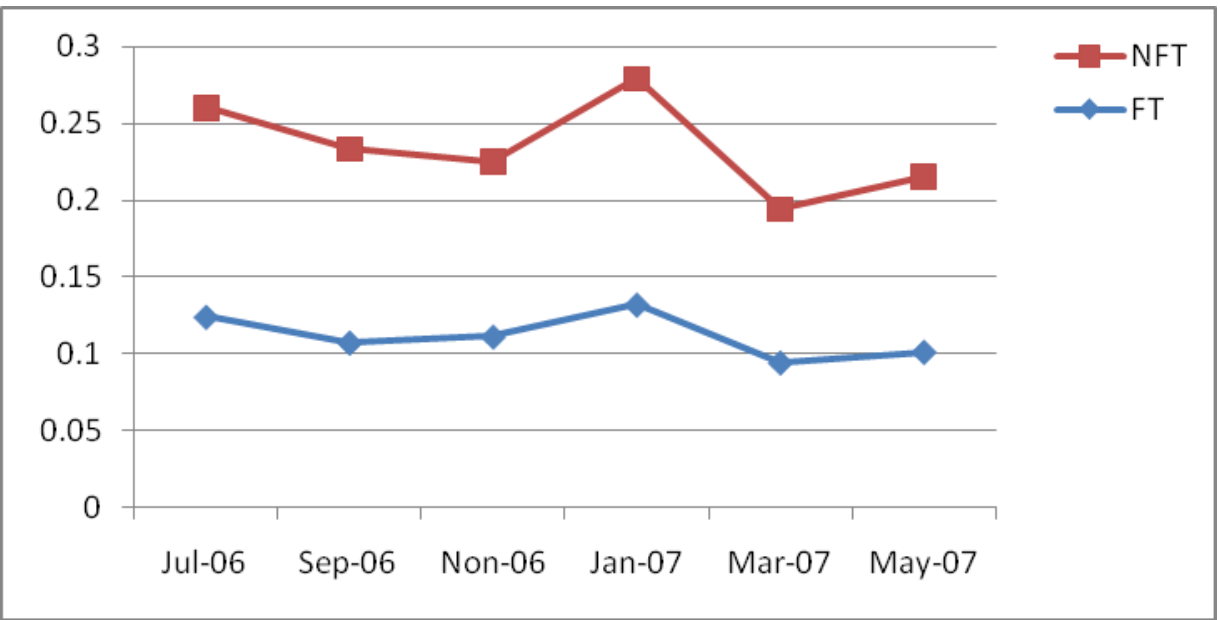

Months 
Fig.5 Mean leaf S content of cashew in different mandals

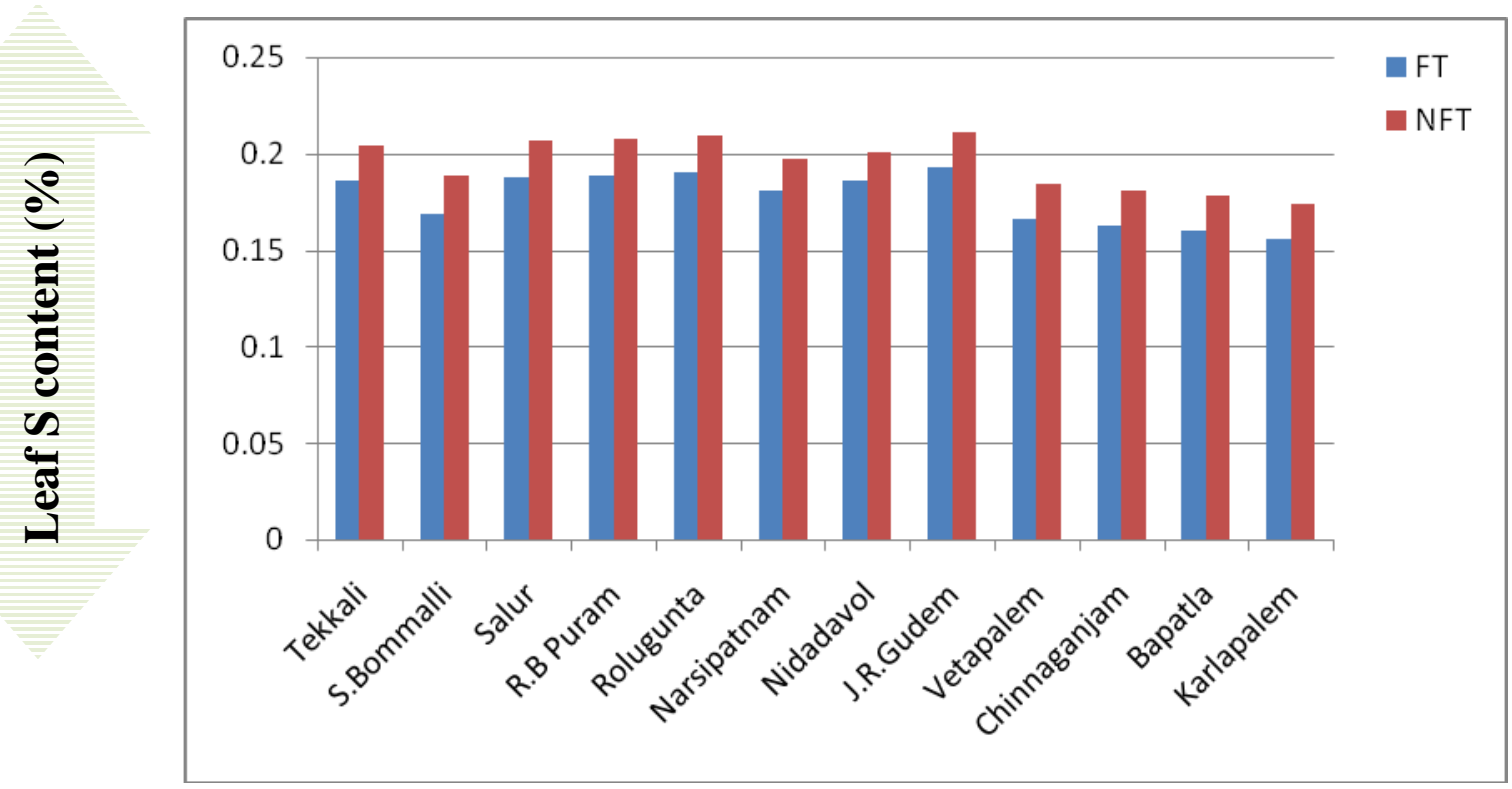

\section{Different mandals}

Fig.6 Mean leaf S content of cashew in different months
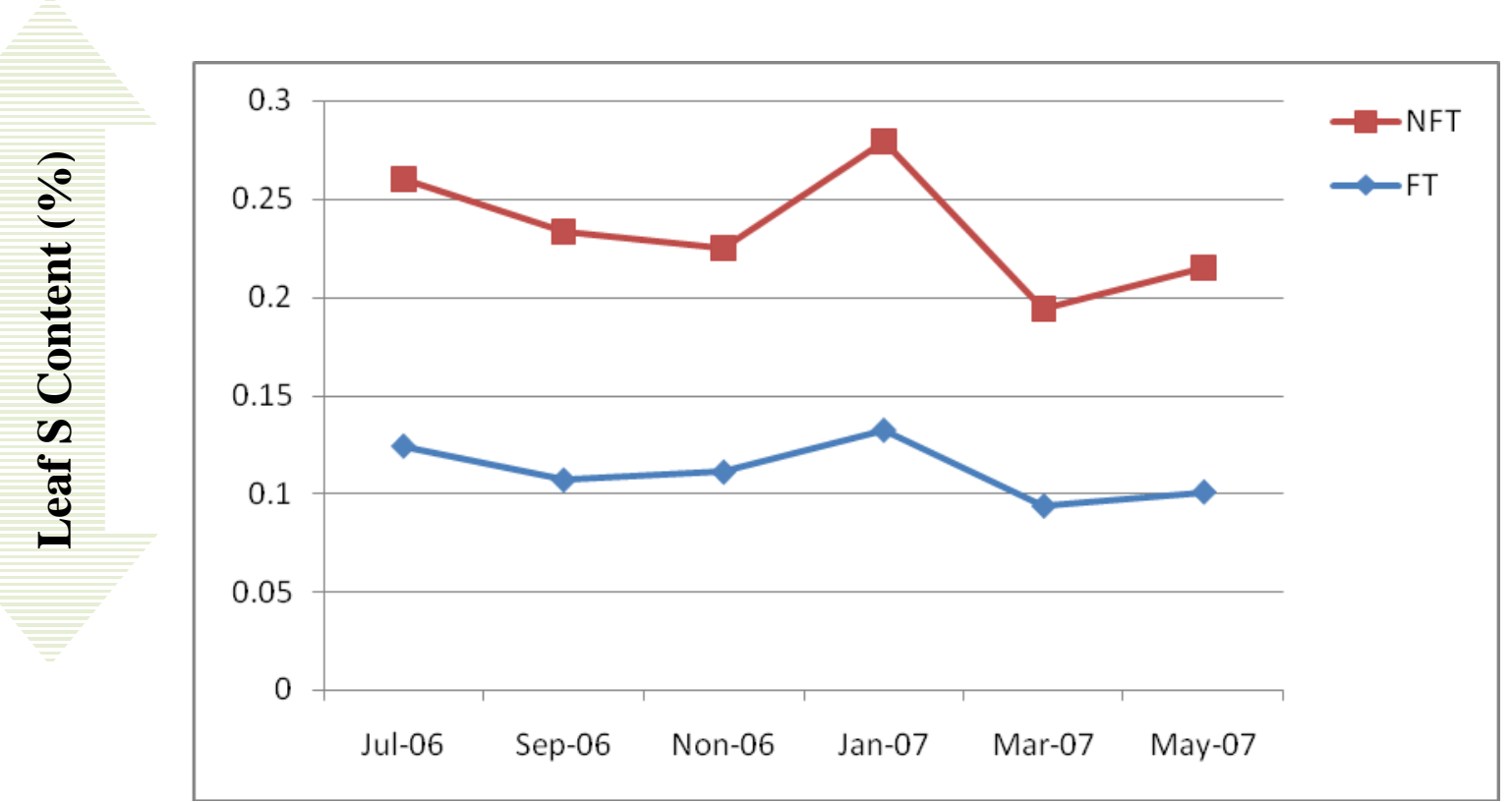

\section{Months}

Beena Bhaskar (1992) reported that the concentration of $\mathrm{S}$ during the post-harvest phase was higher than that during the non- fruiting phase of the plant. Thakur et al., (1981) and Kotur and Singh (1993) reported that the leaf $S$ content in non-fruiting 
terminals was higher than that in fruiting terminals. The greater nutrient concentration in both fruiting and non-fruiting terminals during November to January coincided with the flower bud initiation and formative stage of the plant.

The leaf $\mathrm{Ca}$ in all the twelve mandal cashewnut orchards in different months varied from 0.216 to 0.598 per cent and it ca content was found to be adequate in all the mandals of al coastal districts of Andhra Pradesh. J.R Gudem mandal orchards of West Godavari district recorded higher leaf $\mathrm{Ca}$ content followed by Rolugunta mandal orchards of Visakhapatnam district and Rambhadrapuram mandal orchards of Vizianagaram district. In all the months of study, in general it is observed that non-fruiting terminals recorded higher leaf $\mathrm{Ca}$ content than fruiting terminals. The leaf $\mathrm{Ca}$ content found to be low in March and May but maximum peak was found during the month of November and September.

The leaf $\mathrm{Mg}$ in all the twelve mandal cashewnut orchards in different months varied from 0.141 to 0.234 per cent. The leaf $\mathrm{Mg}$ content was found to be in a low range. J.R Gudem mandal orchards of West Godavari district recorded higher leaf $\mathrm{Mg}$ content followed by Rolugunta mandal orchards of Visakhapatnam district and Salur mandal orchards of Vizianagaram district. In general, the non-fruiting terminals recorded comparatively higher values in all the months but higher values in non-fruiting terminals from July to November and declined from November to May in both fruiting and nonfruiting terminals.

The leaf $\mathrm{S}$ content in all the twelve mandal cashewnut orchards in different months varied from 0.087 to 0.174 per cent. The leaf $\mathrm{S}$ content was found to be in low to adequate range. J.R Gudem mandal orchards recorded higher leaf $\mathrm{S}$ content followed by Nidadavol and Tekkali mandal orchards. In general, it is observed that non-fruiting terminals recorded higher $\mathrm{S}$ content than fruiting terminals. The leaf $\mathrm{S}$ content was fond to be increasing from November to January and thereafter exhibited declining trend up to March by upward trend up to May.

\section{References}

Beena Bhaskar 1992 Uptake pattern of major and minor nutrients in selected cashew types. M.sc (A.g.) Thesis, Kerala Agricultural University, Vellanikkara, Thrissur, Kerala, India, pp. 142.

Bopaiah M G and Srivastava K C 1984 Studies of relationship of soil and leaf nutrient elements in Dashehari Mango. Progressive Horticulture 16 (3-4): 169174.

Bopaiah M G, Thakur R S and Srivastava K C 1989 Studies on some aspects of soil and leaf nutrients in Dashehari Mango. Acta Horticulture 231:352-357.

Cottenie A, Verloo M, Velghe $\mathrm{G}$ and Kie Kins L 1979 Analytical Methods for Plant and Soils. State University, Ghaut, Belgium.

Gujaman-Estradac: mosqueda-Vazquez $\mathrm{Rj}$ Alcadle-Blanco-S, Martinez-Garaz-Aj Lavi-U (ed): Wysoki-M 1997 Macro and micronutrients foliar content variation in mango $\mathrm{Cv}$. Manila Acta Horticulture 455:471-478.

Jackson M L 1973 Soil Chemical Analysis. Prentice Hall of India Private Limited, New Delhi.

Jagadeshkumar T N 2005 Leaf nutrient status -yield interaction in different cashew varieties. The Cashew 20 (2): 28-32.

Koo R C J and Young T W 1977 Effect of age, position and fruiting status on mineral composition of 'Tonnage' Avocado leaves. Journal of American Society of Horticulture Science 102:311-313. 
Kotur S C and Singh H P 1993 Leaf Sampling techniques in Litchi (Litchi chinensis). Indian Journal of Agricultural Science 102:632-638.

Kumar P H, Rakiappan P, Nair B P, Mohan E and Nagabhushanam S 1985 Effect of season, position and age of leaf on the major nutrient composition of cashew. Cashew Research and Development: Proceedings of the International Cashew Symposium, Cochin, Kerala, India. pp. 12-15.

Panse V G and Sukhatme P V 1967 Statistical Methods for Agricultural Workers. Indian Council of Agricultural Research, New Delhi.

Richards 1993 Report on Cashew research in northern territory of Australia. (Tech.Bulletin No.202). CSIRO Coastal Planes Research Station Northern Territory Australia.
Robinson J B, Treeby M T and Stephenson R A 1997 Fruits, nuts and vines. IN: Plant Analysis an Interpretation Manual. (eds. Reuter D J and Robinson J B) pp. 349-82. (CSIRO Publishing: Collingwood, Australia.).

Sanyal D and Mtra S K 1991 Standardization of leaf sampling techniques for mineral composition of Cashew Cv. Red Hazari. The Cashew, pp. 8-11.

Srivastava A K and Singh S 2003 Soil plant nutrient limits in relation to optimum fruit yield of Sweet orange (Citrus sinensis) Cv. Mosambi. Indian Journal of Agricultural Science 73 (4): 209-211.

Thakur R S, Samara J S and Chadha K L 1981. The leaf nutrient levels in fruiting and non-fruiting terminals of three mango cultivars. Scientia Horticulture 15:355-361.

\section{How to cite this article:}

Sathi Babu, N., V. Chandra Sekhar and Dhanasree, K. 2018. Seasonal Variations in the Uptake and Status of the Secondary Nutrients in Leaf Terminals in Cashew in Coastal Districts of Andhra Pradesh, India. Int.J.Curr.Microbiol.App.Sci. 7(09): 3643-3652. doi: https://doi.org/10.20546/ijcmas.2018.709.453 